ИЗВЕСТИЯ АКАДЕМИИ НАУК ЭСТОНСКОЙ ССР. ТОМ 28 ХИМИЯ. 1979, № 3

\title{
КИНЕТИКА ОКИСЛИТЕЛЬНОГО РАДИОЛИЗА НЕКОТОРЫХ ПОЛИЦИКЛИЧЕСКИХ АРОМАТИЧЕСКИХ УГЛЕВОДОРОДОВ
}

Исследование кинетики и макромеханизма окислительного радиолиза полициклических ароматических углеводородов (ПАУ) различного строения, обладающих различной биологической активностью, зачастую и канцерогенными свойствами, имеет существенное значение в познании процессов, управляющих активированной окислительной деградацией канцерогенных веществ в окружающей среде. В естественной и принудительной деградации экзогенных загрязнений среды зачастую принимают участие сразу несколько ПАУ, наличие которых в смеси с бенз(а)пиреном (БП) может оказать влияние на кинетику его окислительного разложения. В данной работе, кроме определения кинетических показателей разложения ряда ПАУ, сделана попытка установить их взаимное влияние при окислении, инициированном $\gamma$-излучением ${ }^{60} \mathrm{Co}$.

\section{Эксперименты и их обсуждение}

Методика экспериментального исследования и связанного с ним физикохимического и аналитического контроля описана в [']. Перечень подвергнутых облучению ПАУ приведен в табл. 1. Растворы ПАУ в «хч» (концентрация $\approx 2 \cdot 10^{-4}$ моль/л) облучались на установке PX- $\gamma-30$ при мощности дозы $\approx 10^{16} э B / M \Omega \cdot c$. Для получения сопоставимых данных для всей серии ПАУ, облученных при разных мощностях, в каждом цикле параллельно облучался раствор БП - как своего рода «внутренний

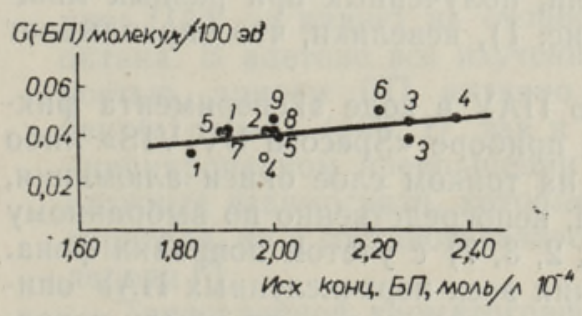

Рис. 1. Зависимость радиационного выхода $\mathrm{G}(-Б$ Б) от исходной концентрации при разных мощностях дозы облучения: $1-0,45 ; 2-0,55 ; 3-0,60 ; 4-0,65$; $5-0,80 ; 6-0,86 ; 7-1,22 ; 8-1,4$ и 9 - $1,7 \quad$ M рад/ч.

3 ENSV TA Toimetised. K 31979

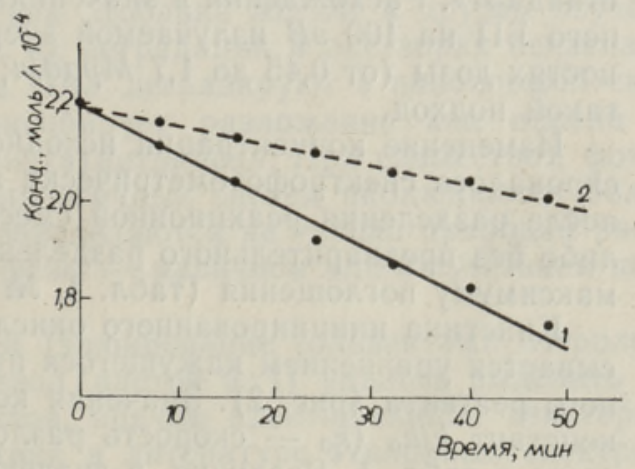

Рис. 2. Разложение бенз (е)пирена в ацетоне раздельно (I) и совместно с БП (2). 
Таблица 1

Изученные ПАУ и кинетическая характеристика их окислительной деградации

\begin{tabular}{|c|c|c|c|c|}
\hline 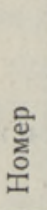 & $\begin{array}{c}\text { Наименование и структурная } \\
\text { формула }\end{array}$ & $\begin{array}{c}\text { Фирма- } \\
\text { изготовитель }\end{array}$ & $k / k_{0}$ & $\begin{array}{c}\text { Радиаци- } \\
\text { онный } \\
\text { выход G } \\
\text { (-ПАУ), } \\
\text { молекул/ } \\
100 \text { эВ }\end{array}$ \\
\hline 1 & Антрацен * & & 1,06 & 0,057 \\
\hline 2 & Фенантрен & Союзхимреак- & 0,25 & 0,012 \\
\hline 3 & Трифенилен & " & 0,17 & 0,008 \\
\hline 4 & Пирен & $"$ & 0,31 & 0,016 \\
\hline 5 & Хризен & Austrowaren & 0,31 & 0,012 \\
\hline 6 & Бенз (a) антрацен & $\begin{array}{l}\text { British Drug } \\
\text { Houses Ltd. }\end{array}$ & 0,74 & 0,025 \\
\hline 7 & Бенз (b) антрацен & Schuchardt & 19,7 & $\approx 0,7$ \\
\hline 8 & Перилен & $\begin{array}{l}\text { Союзхимреак- } \\
\text { тив }\end{array}$ & 0,94 & 0,039 \\
\hline 9 & Бенз (а) пирен & $\begin{array}{l}\text { Fluka AG } \\
\text { Buchs SG }\end{array}$ & 1,0 & 0,044 \\
\hline 10 & Бенз (е)пирен & $\begin{array}{l}\text { Gee Lawson } \\
\text { Chemicals }\end{array}$ & 0,28 & 0.012 \\
\hline 11 & $\begin{array}{l}\text { Дибенз (a, c) антра- } \\
\text { цен }\end{array}$ & & 0,56 & 0,021 \\
\hline 12 & $\begin{array}{l}\text { Дибенз }(\mathrm{a}, \mathrm{h}) \text { антра- } \\
\text { цен }\end{array}$ & " & 0,59 & 0,022 \\
\hline 13 & $\begin{array}{l}\text { Дибенз }(a, j) \text { антра- } \\
\text { цен }\end{array}$ & " & 0,76 & 0,034 \\
\hline 14 & Коронен & $\begin{array}{l}\text { Союзхимреак- } \\
\text { тив }\end{array}$ & 0,48 & 0,019 \\
\hline
\end{tabular}

* Очищен методом, зонной плавки.

стандарт». Расхождения в значениях радиационного выхода превращенного БП на 100 эВ излучаемой энергии, полученных при разных мощностях дозы (от 0,45 до $1,7 \mathrm{Mpad/u;} \mathrm{рис.} 1$ ), невелики, что оправдывает такой подход.

Изменение концентрации исходного ПАУ в ходе эксперимента фиксировалось спектрофотометрически на приборе «Specord UV VIS» либо после разделения реакционной смеси на тонком слое окиси алюминия, либо без предварительного разделения, непосредственно по выбранному максимуму поглощения (табл. 1, № $1,2,3,7$ ) с учетом поправки фона.

Кинетика инициированного окисления всех перечисленных ПАУ описывается уравнением кажущегося нулевого порядка - по убыли исходного реагента (рис. 2). Значения констант скорости $k$ и относительных констант $k / k_{0}$ ( $k_{0}$ - скорость разложения БП в параллельном опыте) даны в табл. 1. Различия в значениях $k / k_{0}$ и радиационного выхода инициированного окисления для изученных ПАУ, за исключением высокореакционноспособного тетрацена, ограничены одним порядком. 
Кинетика раздельной и совместной окислительной деградации бенз(а)пирена в эквимолярных смесях с пиреном, бенз(е)пиреном и бенз(а)антраценом

\begin{tabular}{|c|c|c|c|c|c|c|}
\hline 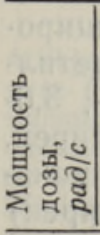 & Pearent & $\begin{array}{r}\text { Раство- } \\
\text { ритель }\end{array}$ & 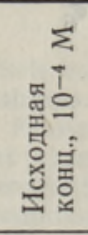 & 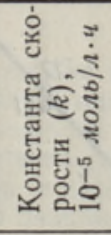 & 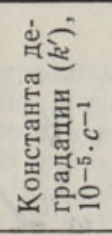 & 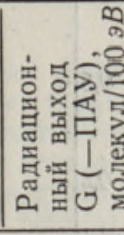 \\
\hline 240 & БП* & $\begin{array}{l}\text { Бензол } \\
\text { Октан } \\
\text { Ацетон }\end{array}$ & $\begin{array}{l}2,20 \\
2,22 \\
1,91\end{array}$ & $\begin{array}{r}2,2 \\
4,5 \\
46,4\end{array}$ & $\begin{array}{r}2,8 \\
5,6 \\
67,6\end{array}$ & $\begin{array}{l}0,025 \\
0,051 \\
0,57\end{array}$. \\
\hline & Пирен & $\begin{array}{l}\text { Бензол } \\
\text { Октан } \\
\text { Ацетон }\end{array}$ & $\begin{array}{l}2,20 \\
2,20 \\
1,98\end{array}$ & $\begin{array}{l}0,51 \\
1,40 \\
5,0\end{array}$ & $\begin{array}{l}0,64 \\
1,76 \\
7,06\end{array}$ & $\begin{array}{l}0,006 \\
0,016 \\
0,06\end{array}$ \\
\hline & Совместно с БП & Ацетон & 2,00 & 3,4 & 4,72 & 0,045 \\
\hline 220 & Бенз (е) пирен & $\begin{array}{l}\text { Бензол } \\
\text { Октан } \\
\text { Ацетон }\end{array}$ & $\begin{array}{l}2,10 \\
1,90 \\
2,20\end{array}$ & $\begin{array}{l}0,45 \\
0,97 \\
6,0\end{array}$ & $\begin{array}{l}0,60 \\
1,42 \\
7,58\end{array}$ & $\begin{array}{l}0,005 \\
0,012 \\
0,072\end{array}$ \\
\hline & Совместно с БП & Ацетон & 2,20 & 2,5 & 3,16 & 0,03 \\
\hline 190 & Бенз (а) антрацен & $\begin{array}{l}\text { Бензол } \\
\text { Октан } \\
\text { Ацетон }\end{array}$ & $\begin{array}{l}1,62 \\
1,94 \\
1,80\end{array}$ & $\begin{array}{c}0,63 \\
1,7 \\
21,2\end{array}$ & $\begin{array}{r}1,08 \\
2,43 \\
32,7\end{array}$ & $\begin{array}{l}0,009 \\
0,025 \\
0,32\end{array}$ \\
\hline & Совместно с БП & Ацетон & 1,80 & 13,6 & 21,0 & 0,22 \\
\hline
\end{tabular}

* Не приводятся кинетические показатели деградации БП в совместных опытах с бенз (е) пиреном и бенз(а)антраценом.

Эксперимент по совместному радиолизу проведен для трех эквимолярных смесей БП: с пиреном, бенз(е)пиреном и бенз (а)антраценом при неизменной исходной концентрации $2 \cdot 10^{-4}$ моль/ $\Omega$ с использованием в качестве растворителей бензола, н-октана и ацетона. Основные кинетические показатели приведены в табл. 2.

Значения констант скорости деградации во всех случаях определяются природой растворителя и убывают в ряду ацетон $>$ октан $>$ бензол. При совместном радиолизе систем БП + инактивные [пирен, бенз (е)пирен] или слабо активный [бенз(а)антрацен] ПАУ выявляется общая закономерность: добавка второго компонента не влияет на кинетику превращения основного канцерогена. Добавка же БП к другим изученным ПАУ не влияет на скорость их деградации в растворах бензола и октана. В ацетоне все изученные ПАУ деградируют с наибольшей скоростью, причем БП активно ингибирует разложение как пирена и бенз (е) пирена (рис. 2), так и бенз (а) антрацена. При совместном фотоинициированном превращении аналогичных систем наблюдаются более сложные взаимосвязи, которые определяются не только природой растворителя, но и составом газовой фазы - наличием или отсутствием кислорода [2].

Тонкослойной хроматографией (элюирование сольвентами петролейный эфир : хлороформ $9: 1$ и бензол: ацетон 9:1) удалось выделить из реакционных смесей ряд продуктов, причем идентификация некоторых из них затруднена из-за отсутствия в литературе эталонных спектров. Наиболее широкий набор продуктов образуется при окислительном радиолизе ПАУ в ацетоне - при инициированном превращении БП в 


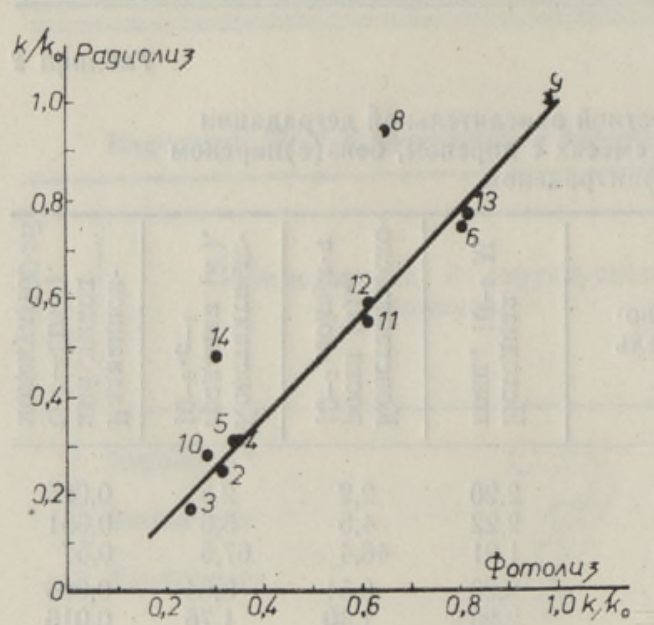

Рис. 3. Сопоставление кинетических данных двух процессов инициированного окисления (фотолиз и радиолиз). Нумерация соединений по табл. 1.

основном образуется его 6-метилпроизводное, но идентифицированы и другие моно- и диметилпроизводные: 1-метил-, 1,6-, 3,6и 3,12 -диметилбенз (а)пирен. Образуются также метилпроизводные (1-метил- и 4-метилпирен) при облучении пирена в ацетоне, причем в реакционной смеси содержатся и $-\mathrm{OCH}_{3}$ - и - $\mathrm{COOH}$ содержащие продукты. Реакции окисления протекают с образованием хинонов: 3,12-, 3,6- и 1,6-хинонов из БП, бенз (a) антрахинона из бенз (а) антрацена, дибенз (a,h)антрахинона из дибенз $(\mathrm{a}, \mathrm{h})$ антрацена. В случае облучения БП в октане протекает частичное гидрирование его молекулы с образованием $7,8,9,10$ тетрагидробенз (а) пирена.

Полученные данные показывают, что суммарный процесс инициированного $\gamma$-излучением окисления ПАУ представляет собой комплекс последовательных и параллельных реакций окисления, восстановления, алкилирования, конденсации и полимеризации.

Значения $k / k_{0}$ (табл. 1) хорошо сопоставимы с соответствующими данными для фотоинициированного окисления тех же ПАУ в бензоле [3] (рис. $3 ; r=0,9945)$, за исключением перилена, коронена и тетрацена. В серии дибензпиренов также наблюдались отклонения от общей хорошей корреляции [4].

Что касается сравнительной эффективности обоих процессов, то фотоинициированное окисление оказывается по всем показателям значительно эффективнее $\boldsymbol{\gamma}$-радиолиза.

\section{Л И ТЕ Р А Т У Р А}

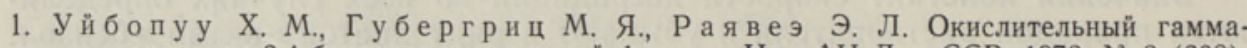
радиолиз 3,4-бензпирена в жидкой фазе. - Изв. АН ЛатвССР, 1973, № 3 (308), c. $116-118$.

2. Паа льме Л. П., Губергриц М. Я. К вопросу о естественной деградации бенз(а) пирена и других углеводородов в составе загрязнений, попадающих в водоемы. - В кн.: Материалы IV Всесоюзного симпозиума по современным проблемам самоочищения и регулирования воды. Таллин, 1972, с. $62-67$.

3. Па альме Л., Т уулметс А., Кирсо У., Губ ергриц М. Реакционная способность полициклических ароматнческих углеводородов в процессе фотоинициированной деградации. - Реакц. способн, орг. соед., 1974, т. 11, вып. 2(40), c. $313-322$.

4. Паальме Л. П., уйбопу у Х. М., Пахапилль Ю. А., Губергриц М. Я., Жакиньон П. С., Бахна Л. Реакционная способность и молекулярная структура бензпроизводных пирена. - В кн.: Окисление канщерогенных полициклических углеводородов производных бенз(а)пирена. Таллин, 1978, с. $50-56$.

Ннститут химии

Академии наук Эстонской ССР

Поступила в редакцию 1/XII 1978 
Helvi UIBOPUU, M. GUBERGRITS, E. RAJAVEE

\section{MONINGATE POLUTSUKLILISTE AROMAATSETE SUSIVESINIKE RADIOLUUSI KINEETIKA}

Artikkel käsitleb mõningate polütsükliliste aromaatsete süsivesinike degradatsiooni $\gamma$-kiirguse $\left({ }^{60} \mathrm{Co}\right)$ toimel hapniku manulusel $n$-oktaani lahuses. Kõigil uuritud juhtudel toimus summaarne lagunemine nulljärku reaktsiooni järgi. Koossüsteemides (bens (a)püreen ekvimolaarses segus kas püreeni, bens (e) püreeni või bens (a) antratseeniga) ei mōjusta bens (a) püreen teise süsivesiniku degradatsiooni kiirust benseenis ja n-oktaanis, kuid aeglustab kõigi kolme lagunemist atsetoonis, kusjuures teise komponendi lisamine ei mõjusta bens (a) püreeni degradatsiooni üheski nimetatud solvendis. Degradatsiooni kiirus sõltub kasutatud lahusti loomusest ja väheneb järjekorras atsetoon $>n$-oktaan $>$ benseen.

Määratud kiiruskonstandid on heas vastavuses fotonitsieeritud degradatsioonil saadud tulemustega.

Helvi UIBOPUU, M. GUBERGRITS, E. RAJAVEE

\section{THE KINETICS OF OXIDATIVE RADIOLYSIS OF POLYCYCLIC AROMATIC HYDROCARBONS}

The kinetics of $\psi-\left({ }^{60} \mathrm{Co}\right)$ initiated oxidation of a series of polycyclic aromatic hydrocarbons (PAH) in $n$-octane solution was studied and the apparent zero-order of the total reaction was established. In binary systems (the equimolar $2 \cdot 10^{-4} \mathrm{M}$ solutions of benzo(a) pyrene with pyrene, benzo(e)pyrene or benzo(a) anthracene) the added PAH did not influence the degradation rate of benzo(a)pyrene in benzene, $n$-octane or acetone. The benzo(a)pyrene had no influence on other PAH in benzene and $n$-octane, but inhibited their oxidation in acetone. The rate of the oxidative radiolysis of PAH depends on the nature of the solvent and decreases in the order acetone $>n$-octane $>$ benzene.

The kinetic data on the radiolytic oxidative degradation of PAH are in a good accordance with corresponding data on their photooxidation. 